\title{
Moving Beyond Identity-Based Solidarity: \\ Transnational Moslem Community Engagement toward the Rohingya Refugees
}

\author{
Taufik Hidayat, Deasy Silvya Sari, Siti Aliyuna Pratisti \\ International Relation Department \\ Universitas Padjadjaran \\ Bandung, Indonesia
}

\begin{abstract}
The Rohingya conflict in Myanmar raises critical humanitarian issues which lead to multiple waves of refugees fled to various countries for protection. The indifferent act of the Myanmar government showed toward the Rohingya indicates the occurrence of structural violence that voiced by the international community, including Indonesia. A great deal of attention was given by the Indonesian government by continuing to carry out humanitarian assistance. However, behind the Indonesian government cosmopolitan policy in dealing with the Rohingya refugees, there are major roles of Moslem communities such as Dompet Dhuafa, ACT, and other civil society that encourage a change of perspective of Indonesian government toward refugees. In addition, this paper will also discuss forms of solidarity involving various parties, ranging from government, non-government organizations to the grassroots community, as an effort to fulfill the basic rights of refugees. The impartiality of solidarity promoted by various Moslem communities in Indonesia has become a framework for encouraging civil society engagement toward refugees, regardless of their identity. Hand in hand with government, transnational Moslem community can be a leading actor in voicing solidarity, beyond the boundaries of identity.
\end{abstract}

Keywords: transnational Moslem community; civil society; solidarity

\section{INTRODUCTION}

The international community recently shocked by violent acts ranging from terrorism to civil war that occurred in various parts of the world. Southeast Asia itself is not immune from the conflict, and one that surfaced relentlessly was the identity conflict in Myanmar with the Rohingya as victims. The root of the conflict between the majority community in Rakhine and the Rohingya minority is not new discriminatory policies have been imposed by the British colonial period through the separation of the settlement between the Myanmar Buddhist and the Moslem Rohingya. The form of discrimination against the Rohingyas became more prominent when the military junta's regime declared that the Rohingyas were not part of Myanmar through the Burma Citizenship Law (BCL) in 1982. This policy resulted in the abolition of citizenship rights, land rights, the right to have basic education and decent work for the ethnic Rohingya[1]. This discrimination culminated when the Rakhine people committed violence against Rohingya that resulted in the massive waves of refugees to various countries, including Indonesia.

The form of violence suffered by the Rohingya contradicts Article 15 of the Universal Declaration of Human Rights of the United Nations (1948) which obliges states to protect every of its citizen. In addition to the violations of state responsibility for its citizens, the Rohingya conflict also intersects with identity issues. The construction of identity conflict arose because the Buddhist majority of Myanmar was seen to ignore the violence done against the Rohingya Moslem minority. This view creates a new level of attention to the Rohingya conflict in Myanmar with the widespread transnational solidarity voiced by Moslem societies in various countries. Indonesia, as one of the Moslems majority, showed how solidarity moved its people in a significant measure. Through various forms of protests directed at Myanmar's representatives in Indonesia, the solidarity of fundraising, and through the direct distribution of aid to victims and Rohingya refugees, Moslem communities in Indonesia has joined their arm and voiced their concerns for the Rohingya.

There is no doubt that solidarity to the Rohingya refugees is widely voiced by the Moslem community has wide coverage from transnational network to small communities in society. This phenomenon raises a crucial paradox in humanitarian action, since the solidarity driven by a sense of identity, is opposite to the principle of humanitarian assistance that based on impartiality. Defined as the cultural, social and political values that attached to a person or group, identity puts a dividing wall between in-group and out-group. The Rohingya conflict shaped by this particular construction of identity, related conflict related 
to an intersection of values and interests of the identities of the disputed groups. An ethnic and religious identity that often used as common perspective toward the Rohingya conflict, plays a massive role in bringing together diverse individuals through the common experience and perception of cultural values [2]. The thick characterization of ethnic and religious conflict has brings solidarity from a cross-national religious community, especially the Moslemcommunities that give humanitarian aid in a significant amount. However, ethnic solidarity tends to take sides, while the main principle in humanitarian aid goes against it. Based on this paradox, this paper attempts to outline the formation of solidarity among the various Moslem communities in Indonesia, and how they manage to move beyond the limits of identity and maintains the principle of impartiality in the handling of the Rohingya conflict.

\section{IDENTITY, CiVIL SOCIETY AND TRANSNATIONAL SOLIDARITY}

A form of solidarity coupled with identity conflict is not a new discourse in the context of international relations. History has recorded the consistent solidarity showed by the Moslem communities to the Palestinian independence, or post-independence solidarity of the countries in Asia-Africa has underlined the Non-aligned movement. However, the current globalization of information makes transnational solidarity increase prominently. Through the rapid flow of sharing information, the Rohingya conflict, no longer domestic issue in Myanmar, but also a problem to the world. The global public's attention to the Rohingya emerged in a stronger dimension, especially in Moslem societies. The strength of this solidarity arises on the basis of identity - in other words, it is Islam's identity that works as the prime driven for the involvement of the Moslem communities and solidarity toward the Rohingya. Identity brought up a "collective sense", a construction that refers to an individual's sense of belonging to an ingroup that in its formation can be driven by phenomena within or interaction with another group [3]. In the case of violence against Rohingya, the fact that victims are Moslem has caused waves of sympathy from other Moslem societies based on this emotional sense of identity ties.

In the handling of the Rohingya refugees that castout from their home, solidarity emerges in the form of civil society movement that opposite to silent policy from the Association of South East Asian Nations (ASEAN). The nonintervention principle that upheld by ASEAN members is a major obstacle to the involvement of ASEAN in handling the victims as well as in the settlement of the Rohingya conflicts. While states face its limits on the basis of the nonintervention principle, the civil societies, which are free from political interest, taken over the role of reconciliation party and come up with a real solution. In Southeast Asia itself, protests against Myanmar policy toward the Rohingya, distinctly voiced by a number of civil society movements through the network of transnational communities. In Indonesia, the attention toward the Rohingya conflict is being actively voiced by several Moslem communities considering Indonesia is a country with a Moslem majority population. In this context, the emerging transnational Moslem community in Indonesia is the realization of a new social space that encourages the participation of individuals to design a concrete action toward the issue of Rohingyas. Through the case study of the handling of Rohingya refugee done by Moslem communities, it can be seen how civil society can establish transnational solidarity amid the barriers of national boundaries.

The concept of transnational relations itself is defined as interactions that take place across national boundaries where the interactions involve, at least one non-state actor who interact outside the government policy framework [4]. Basically, the form of transnational relations is not a new phenomenon. The interaction between communities such as trades, diplomatic communications or personal interaction, have been perpetrated over the centuries [5] Along with the increasing of interaction and the more significant role of non-state actors, the conceptualization of transnational relations is finally accepted as an imperative phenomenon in international relation. The theoretical studies of this trans-boundaries relations described by Robert 0. Keohane and Joseph S. Nye as Transnational Relations. Through this theoretical explanation, the study of transnational relations gained a prominent place in the agenda of world politics and giving a significant influence on the basis of changes in social interaction, pluralism, and interdependence [6]. Furthermore, transnational relations as a form of interaction in international relations generally can be described in two ways. First, world politics must make a room for increasingly non-state actors. And second, the erosion of state control over 
various activities and cross-country interaction. These two aspects give transnational relations its fundamental stepping stone in social discourse.

The social subject in transnational relationships is the community of individuals who have the will, identity, and capability of connecting in various forms of collective action that can be identified as the fabric of the subjectivity of the integration of individuals in the social system. Individuals have complex cultural and identity references (such as values, religiosity, ethnicity, and gender) that can occupy different positions in social systems (as employees, leaders, politicians, and academics). The ideas embedded in the social community were, in the past, articulated in a heroic national, national, and transnational movement, such as feminism, pacifism, anti-nuclear movement, antiapartheid, human rights activists, environment, and so forth. However, when discussing the linkage between social movement and identity, there is a dual condition emerge. On the one side, identity can bring solidarity, but on the other side, it is a common knowledge that identity is also responsible for some gross social violence. These two constructions of identity can be found in the Rohingya conflict - as an instrument to the conflict on one hand, and as the voice for transnational social movements on the other.

In its interaction, the transnational social movement consists of actors who have a creative capacity and desire to change. This movement is involved in various issues that highlight social justice that took form in civil society or foundations that engage in a transnational transaction of exchanging ideas or funds. The goal of the transnational social movement is to uphold critical awareness as a collective action that encourages the development of elements of solidarity. Transnational social movement unites various actors, social conditions, and movements (organizations), also combining moral values and direction of attitudes. In the context of solidarity, equality is recognized and conflict negotiated (internally and externally), embracing plurality and diversity and seeking solutions to divisions. Meanwhile, solidarity in transnational social movements is driven by the effective diffusion of two things, namely the similarity of values or the similarities of identity. Transnational solidarity may arise in a non-symmetrical form: it can consist of nations, communities or independent individuals. Individual form in some cases often labeled as having a degree of blind faith. The blind faith phenomena also found in the solidarity of Indonesian society to the Rohingya, since some of them are driven to support Rohingya only on the basis of certain identity similarities, without even knowing the real problem.

The linkage of identity factors in the international community is proposed by Milani and Laniado [7], who argue that every transnational social movement is always driven by identity ties. The affirmation of identity in the transnational movement is not only referring to the realization of political ideas, but also to the universal issue of global problems. The indication of the presence of the identity element in the transnational movement is reflected in the symbolic elements (such as religion, race, sex, nation, to minority groups). Identity is the basis of construction that moves individuals to contribute, either formally or personally. Today, identity becomes a traditional power structure capable of providing another view of transnational political issues. Through its various roles in today's international issues, it is clear that transnational solidarity has contributed significantly, one of them by building an advocacy network for humanitarian cases [8]. Through its pattern of interaction, this transnational movement of solidarity mobilizes through existing local organizations, while framing and exchanging information is conducted through a network of transnational activities.

\section{Transnational Moslem Community: Moving BEYOND THE LIMIT OF IDENTITY}

The idea of a transnational society refers to "a community consist of individuals or groups formed in different national societies, and acting on the basis of common interests and references (which may be territorial, religious or linguistic), and networks used to strengthen their solidarity outside boundaries of the state" [9]. In its development, the transnational community is a "new social space" built on transnational networks of different groups in different countries or networks, connecting actors from various countries, and encouraging the participation diaspora groups of their double national identities. The basic formation of transnational communities is a cross-national political action, whether at the level of ideas, behavior, identity or other elements as the basis of social capital. In a sense, the transnational community establishes its own identity. The associative dimension is the basis of transnational community networks, where there 
is a process of building and maintaining various social relationships between communities.

In a more specific form, transnational movements can be identified as religious actors, which play a role not only at the domestic level but also at the transnational level. Some examples are the Vatican-based Catholic Church Network, the North American Evangelical Protestants that changed the political order in Guatemala in the 1980s, or the Organization of Islamic Conference that began in 1969 - are valid evidence that transnational religious actors have developed an extensive transnational links which are important ramifications for the development of local and interstate religious-political cultures [10]. The transnational movement of Islam itself was initially driven by political foundations, such as the Moslem Brotherhood that encouraged the political existence of the global Moslem community. However, in its development, another form of transnational Moslem community emerged and built a vast network of various non-governmental organizations working in the field of humanity. Its existence not only deals with humanitarian problems within Moslem countries but also engages with various problems and by collaborating with communities in other countries.

The Rohingya refugee issue provides an illustration of how the network and interaction among transnational Moslem communities in Indonesia. Some of the communities involved include are Dompet Dhuafa, Pos Peduli Peduli Umat (PKPU), Aksi Cepat Tanggap(ACT), Al-Falah Social Fund Foundation, are some example of the many other communities that involved. This community movement becomes a channel for solidarity when the state is hampered by bureaucratic and political problems. The position of Indonesia's government that doesn't yet ratify the international convention on refugees, as well as the attitude of ASEAN that chose to keep a distance to the domestic problems of its member, becomes a major obstacle in Indonesia's involvement in the handling of the conflict in Myanmar. But with the encouragement and support of various Moslem communities, Indonesia eventually played an active role in this complex social issue. This support itself took several forms: (1) fundraising, (2) advocacy networks, (3) humanitarian treatment, and (4) peace-building efforts. These forms of supports have illustrated of how the Moslem communities in Indonesia built two main patterns of their interaction. First pattern showed by communities in strengthening solidarity through identity ties among the Indonesian Moslem community. While the second is the pattern of a humanitarian mission where the communities manage to put aside the barrier of identity as they are obliged to the principle of impartiality.

The first pattern of interaction of the transnational Moslem community is closely related to identity-based solidarity. This pattern includes fundraising and the establishment of advocacy networks. In mobilizing aid and donation - PKPU, Dompet Dhuafa, ACT and other Moslem communities, conducted humanitarian campaigns by spreading leaflets and flyers via social media or socialization to the public via dialogues in mosques or other Islamic centers. Indonesia, as a Moslem majority country, is one of the largest contributors in providing assistance for the Rohingya. This wide attention is closely related to the identity solidarity - that the suffering of Rohingyas who are also Moslems, has mobilized various circles of communities to donate. In this pattern, the diffusion of identity gives solid evidence that solidarity movement at the community level is strongly influenced by identity ties factors. Sympathy based on identity not only is also shown by the Moslem community in Indonesia but also from various transnational communities from other countries that make a contribution to the Rohingya conflict resolution, based on the similar patterns. Many of the transnational communities who entrust their donations for the Rohingya refugees, such as the shelter built in Aceh for examples, are Moslem communities. One of the transnational donators is Al-Imdaad, a transnational Moslemcommunitybased in South Africa, Britain, Australia, and Japan.

Another form of support that closely related to the identity-based solidarity is the establishment of advocacy network. It is undeniable that the transnational Moslem community in Indonesia has a close relationship with other Moslem communities abroad in the form of networking and advocacy. In dealing with the Rohingya conflict, a number of transnational Moslem communities doing their advocacy by establishing the Southeast Asia Humanitarian Meeting (SEAHUM), a committee established for humanitarian issues in Southeast Asia. SEAHUM was initially formed to respond the Rohingya crisis thoroughly, not just the issue of refugees and displacement. Since its inception in 2012, there are various transnational communities in Southeast Asia that have responded to this network of advocacy. In Indonesia alone, there are a number of 
communities that joined, including Dompet Dhuafa, Rumah Zakat, ACT, also followed by Muhammadiyah and Nahdatul Ulama (NU). There are also Moslem communities from Malaysia such as IKRAM, Amal Malaysia, and the Moslem community of Thailand who also responded. In its development, SEAHUM not only dealing with the Rohingya conflicts but also expands its function of advocacy on other human rights issues in Southeast Asia. Aside from being an advocating committee, SEAHUM also serves as an arena for coordinating various communities that involved. For example, in the case of handling the Rohingya refugee, there is a division of tasks shared by Moslem communities. For instance, who responsible for shelter and accommodation of the refugees is ACT, while PKPU is responsible for health problem of the refugees and Dompet Dhuafa in handling the aspects of education and trauma healing. This coordination facilitates the division of tasks and avoids overlap duties among different communities.

As for the latter pattern of interaction which based on impartiality is characterize the humanitarian function of the Moslem communities. At this point, the Moslem community eliminates the limits of identity by applying its duties based on the principle of humanity and impartiality. The main goal of the Moslem communities in helping the humanitarian crisis is to bring the victims of conflict to live as decent as human beings in general. This goal also applied in dealing with conflict in Myanmar, the humanitarian aid itself is not only given to the ethnic of Rohingya, but the entire society affected by the conflict, including the Rakhine, the ethnic that live in the same province as the Rohingya. Another example of impartiality held by transnational Moslem communities appears in the selection of their target of humanitarian mission. The mission also was given to countries such as Haiti and the Philippines - which is not a Moslem country. Another elimination of identity barrier is also reflected in the cooperation between interfaith organizations in the handling of Rohingya refugees in Indonesia, since the implementation of the humanitarian assistance of the Moslem community in Indonesia cannot run without the help from other religious communities, such as the Wali Buddhist Indonesia (Walubi) and the Indonesian Catholic Church communities.

The impartial principle is also important to be the endeavor in peacebuilding efforts. In the case of Rohingya, the Moslem community that made to reach Rakhine, not only approached the
Moslem community, but also the Buddhist community of Rakhine. This is crucial because in building understanding between ethnic groups, the horizontal dialogue is taken important place as the heart of the conflict reconciliation. Impartiality became a major foothold given the inherent complexity of the conflict in Myanmar. Identity and religion, in this case, is merely a construction that emerges as a fuel to maintain hatred and conflict. It is not the root which caused prolonged conflict in Myanmar. Other issues such as historical background and social economic conditions should also be considered in order to understand the present conditions. Referring to the flow of history, the problems occurred today in Myanmar, are rooted in the complex problems over the seizure of political institutions. This condition is in line with further elaboration of social studies, that the concept of identity includes an understanding of individual or group behavior toward their social roles, so that conflict of identity also refers to conflict with social strata. By looking at this context, it is only through the principle of impartiality that the transnational Moslem community can serve as an instrument of humanitarian diplomacy, beyond its limits of identity.

The two patterns of solidarity illustrated how the paradox lies in the formation of solidarity within the Moslem community in dealing with humanitarian issues. On the one side, we cannot be denied that identity plays an important role in raising and binding solidarity. But on the other side, humanitarian solidarity should be boundless and without identity barriers. This paradox is faced by transnational communities, especially communities based on religious identity. So it is important to the community to communicate ideas of impartiality and not using identity issues merely for the sake of fundraising. After all, we cannot overcome a conflict if the approach is partial and not comprehensive.

\section{ConClusion}

The state's obstacles in dealing with domestic conflicts encourage transnational Moslem communities to play an active role. In carrying out its humanitarian mission, the Moslem community refers to the philanthropic support of Islamic society in fundraising and networking of cross-border communities, working in the humanitarian field. The handling of Rohingya conflicts (as well as the handling of Rohingya refugees in Indonesia) provides an interesting overview of the patterns of solidarity. Basically, supports from the Moslem communities formed 
in the act of fundraising, advocacy networks, humanitarian handling, and peacebuilding efforts - shared similarities in character with other humanitarian organizations approach. However, these forms of supports illustrate how the Moslem community in Indonesia built two main patterns of interaction:first, by strengthening solidarity through identity equality among the people, and second, by applying impartiality to its humanitarian mission. In practice, these two patterns become the main social forces for the transnational Moslem community.

Another interesting phenomenon related to the role of the Moslem community in the ${ }^{[7]}$ Rohingya case is how the transnational community is able to encourage the government to put more attention to humanitarian issues in Myanmar. This encouragement manifested by the formation of the Indonesian Humanitarian ${ }^{[8]}$ Alliance for Myanmar, comprising of government agencies and various transnational communities. Coordination is also made between the Moslem ${ }^{[9]}$ communities and the International Organization, including the United Nations High Commissioner for Refugees (UNHCR) and the International Organization for Migration (IOM). Through the 11 encouragement from Moslem communities, the government of Indonesia issued a change in the government's regulation on refugees through Presidential Decree No. 125/2016 on the procedures for handling refugees from abroad. The facts showed above is revealed that although religious identity plays an important role in fostering solidarity, however in a humanitarian mission, the community must remain in an impartial humanitarian principle.

\section{REFERENCES}

[1] A. Chan, "The development of a Moslemenclave in Arakan (Rakhine) State of Burma (Myanmar)", London: SOAS, 2005.

[2] M.C. Ross, Cultural Contestation in Ethnic Conflict, New York: Cambridge University Press, 2007.

[3] R. Luhtanenand J. Crocker, "A collective selfesteem scale: Self-evaluation of one's social identity", in Personality and Social Psychology Bulletin, 18, pp. 302-318, 1992.

T.R. Kappen, Structures and International Institutions, Cambridge: University Press, 1995.

A. Wolfers, "National security as an ambiguous symbol", in A. Wolfers, Arnold (ed.), Discord and Collaboration: Essays on International Politics, Baltimore: John Hopkins University Press, pp. 147-165, 1962,.

J. Nye and R. Keohane, "Transnational relation and world politics" in International Organization. 2(3). pp. 329-349, 1971.

C. R. S. Milani and R. N. Laniado, "Transnational social movements and the globalization agenda: a methodological approach based on the analysis of the world social forum", in Brazilian Political Science Review, 1(2), pp. 10-39, 2007.

C. Beck, "The contribution of social movement theory to understanding terrorism", in Sociology Compass, 2(5), pp. 1565-1581, 2008.

R. Kastoriano, "Immigration, transnational communities and citizenships", in Journal Revue Internationale des Sciences Sociales, 16(5), 2000, pp. 353-358

J. Hayness, "Transnational religious actors and international politics", in Third World Quarterly, 22(2), pp. 143-158, 2001 